\title{
Limbal transplantation at a tertiary hospital in Brazil: a retrospective study
}

\author{
Transplante de limbo em hospital terciário no Brasil: estudo retrospectivo
}

Pedro Bertino Moreira ${ }^{1,2}$, Renata Soares Magalhães ${ }^{1,2}$, Nicolas Cesario Pereira ${ }^{2}$, Lauro Augusto de Oliveira ${ }^{3}$, Luciene Barbosa de Sousa ${ }^{3}$

\begin{abstract}
Purpose: Epidemiological analysis of limbal transplantation surgeries performed in the Ophthalmologic Hospital of Sorocaba.

Methods: Retrospective medical records review of 30 patients who underwent limbal stem cell transplants between January 2003 and March 2008. Cases involving conjunctival limbal autograft were classified as group I, and those involving conjunctival limbal allograft as group II.

Results: Two patients were excluded due to incomplete data during postoperative follow-up. Of the total sample of 28 patients, $53.6 \%$ constituted group I, whereas $46.4 \%$ were included in group II. Males were predominant (67.9\%), and right eyes were the most prevalent (67.9\%). The mean age was 40.3 years. Unilateral cases accounted for $60.7 \%$. The most frequent pathology causing limbal system failure was chemical burns (53\%). The mean length of time from diagnosis to surgery was 11.18 years. The limbal graft and amniotic membrane were associated in $75 \%$ of all cases, and tarsorrhaphy in $57.1 \%$. The average follow-up period was 24.84 months. The uncorrected visual acuity improved in $38 \%$ of the cases, was unchanged in $28.5 \%$, and deteriorated in $33.3 \%$. There was no persistent epithelia defect in $75 \%$ of the patients. The conjunctivalization rate was similar between the groups ( $53.3 \%$ and $58.3 \%$, respectively). The transparency improved in only $38.4 \%$ of the cases, and $28.5 \%$ of the surgeries performed were successful. The most prevalent complication was persistent epithelial defect, which occurred in $25 \%$ of the patients, followed by corneal melting in $14.2 \%$. Other complications observed included infectious ulcers, limbal graft necrosis or ischemia, perforation, and descemetocele.
\end{abstract}

Conclusion: Chemical burns remain the main cause of limbal stem cell deficiency. In these cases, limbal transplantation is the standard procedure to restore the ocular surface even though the success rate is low.

Keywords: Limbus corneae; Transplantation, autologous; Transplantation, homologous; Stem cells; Conjunctival diseases; Burns, chemical

\section{RESUMO}

Objetivo: Análise epidemiológica dos transplantes de limbo realizados no Hospital Oftalmológico de Sorocaba.

Método: Foi realizada uma análise retrospectiva através de revisão de prontuário de trinta casos de transplante de limbo realizados no período de janeiro de 2003 a março de 2008. Casos de transplante de limbo autólogo foram classificados como grupo le alogênicos como grupo II.

Resultados: Dois pacientes foram excluídos da análise por insuficiência de dados nos registros. Da amostra completa de 28 pacientes, 53,6\% constituíram o grupo I enquanto $46,4 \%$ o grupo II. O olho direito (68\%) e o sexo masculino (68\%) foram mais acometidos, com uma média de idade de 40,3 anos. Casos unilaterais contabilizaram $60,7 \%$. A patologia de base causadora da deficiência límbica mais prevalente foi a queimadura química (53\%). A média do tempo de doença até a cirurgia foi de 11,18 anos. Na maioria dos casos o transplante foi associado a membrana amniótica (75\%) e tarsorrafia (57\%). O tempo médio de seguimento foi de 24,84 meses. Foi observado melhora da acuidade visual não corrigida em 38\% dos casos enquanto 28,5\% permaneceram inalteradas e 33,3\% pioraram. Evolução sem defeito epitelial persistente ocorreu em $75 \%$ dos pacientes. A taxa de conjuntivalização foi semelhante nos 2 grupos (53,3\% e 58,3\%). Em apenas 38\% dos casos houve melhora da transparência. A taxa de sucesso foi de cerca de $28 \%$. A complicação mais prevalente foi defeito epitelial persistente (25\%) sequida de melting (14,2\%). Outras complicações observadas foram úlceras infecciosas, necrose ou isquemia do enxerto, perfuração e descemetocele.

Conclusões: Aqueimadura química permanece como principal patologia causadora de deficiência límbica. Nestes casos o transplante de limbo é atualmente a técnica de eleição para restauração da superfície ocular, porém com baixa taxa de sucesso.

Descritores: Limbo da córnea; Transplante autólogo; Transplante homólogo; Células-tronco; Doenças da túnica conjuntiva; Queimaduras químicas

\section{INTRODUCTION}

The epithelium of the limbus and cornea ensure the functional and anatomical stability of the normal ocular surface of the human eye ${ }^{(1)}$. Ridges in the conjunctival epithelium toward the peripheral corneal epithelium can be noted in the corneoscleral limbus, which were first described in 1921, and are now known as the palisades of $\operatorname{Vog}^{(2)}$. Fifty years later, Davanger and Evensen suggested that these ridges harbor corneal epithelial precursor cells $s^{(3)}$.

In 1983, Thoft and Friend put forth a theory, known as XYZ, which determined the role of limbal stem cells in corneal epithelium renewal and maintenance ${ }^{(4)}$. The corneal epithelium is in a state of constant renewal to ensure ocular surface maintenance, and this homeostasis depends on limbal stem cells.
Some situations, including thermal and chemical burns, autoimmune diseases, limbal failure secondary to contact lenses use, cryotherapy, or radiation, may alter or reduce the ability of the limbus to serve as a source of stem cells. In the wake of limbal stem cell deficiency, chronic epithelial defect, recurrent corneal erosion, neovascularization, chronic inflammation, fibrosis, and squamous metaplasia may occur ${ }^{(5)}$.

Currently, the most common surgical technique to restore normal limbal physiology is limbal stem cell transplantation (LSCT) ${ }^{(5)}$. The donor tissue can be taken from the same eye (ipsilateral conjunctival limbal autograft [CLAU]), the contralateral eye (contralateral CLAU), from a human leukocyte antigen (HLA)-matched relative (living-related conjunctival limbal allograft $[\mathrm{Ir}-\mathrm{CLAL}])$ or from a cadaver (c-CLAL),
Submitted for publication: December 17, 2014

Accepted for publication: May 14, 2015

Hospital de Olhos (INOB), Brasília, DF, Brazil.

2 Hospital Oftalmológico de Sorocaba, Sorocaba, SP, Brazil.

${ }^{3}$ Department of Ophthalmology and Visual Sciences, Escola Paulista de Medicina (EPM), Universidade

Federal de São Paulo (UNIFESP), São Paulo, SP, Brasil.
Funding: No specific financial support was available for this study.

Disclosure of potential conflicts of interest: None of the authors have any potential conflict of interest to disclose.

Corresponding author: Pedro Bertino Moreira. Rua Monte Alto, 103 - Campinas, SP - 13090-763 Brazil - E-mail: bertinop@gmail.com

Approved by the following research ethics committee: Hospital Oftalmológico de Sorocaba em reunião de 24 de janeiro de 2012. CEP/HOS - 056/2011. 
depending on the severity and unilaterality or bilaterality of the clinical condition ${ }^{(6)}$.

The purpose of this study is to report on the experience of the Ophthalmologic Hospital of Sorocaba (HOS), a tertiary teaching hospital, in performing these procedures, as well as the success and failure rates and associated complications.

\section{METHODS}

This is a retrospective study conducted between January 2003 and March 2008. During this period, 30 LSCT procedures were performed.

This study was approved by the Research Ethics Committee of the HOS, and adhered to the recommendations of the Declaration of Helsinki.

Any patient undergoing LSCT during the time of the study, regardless of the cause of limbal failure, patient age, or severity, was included in the study. Patients who did not undergo sufficient postoperative follow-up to determine the failure or success of the procedure were excluded. Two patients were excluded. Cases involving autologous grafts were classified as group I, and those involving allogenic grafts as group II.

A fellow surgeon assisted by an experienced cornea surgeon performed all the surgical procedures. All surgeries were performed under peribulbar anesthesia with $2 \%$ lidocaine. In group I, two fragments of the limbus and bulbar conjunctiva were obtained from the upper and lower regions of the healthy contralateral eye (CLAU). In group II, the grafts were obtained either from a living-related donor (Ir-CLAL) after human leukocyte antigen I and II typing and crossmatching or from cadaver donor tissue (c-CLAL). In the recipient eye, a complete conjunctival peritomy was performed, followed by a lamellar keratectomy to remove fibrous pannus from the cornea. The limbal fragments were attached to the upper and lower limbus using a 10-0 monofilament nylon suture (Figure 1). In cases in which the amniotic membrane (AM) was used, it was placed either over or under the graft, or both over and under ("sandwich" technique).

The postoperative regimen was not standardized but all cases included corticosteroids and antibiotic eye drops (minimum of 4 weeks and 2 weeks, respectively) and preservative-free artificial tears. Systemic immunosuppression was implemented as a standard procedure in cases of c-CLAL and in Ir-CLAL in which histocompatibility was not 100\%. Systemic immunosuppression regimen and management were determined by a referred nephrologist and were not available in the medical records.

The data analyzed in this study included: gender, age, operated eye, condition causing limbal failure, time elapsed from the onset of the disease until surgery, unilaterality or bilaterality, autologous or allogenic transplantation, kinship of the donor in the case of allogenic transplantation, limbal extension, use of AM and positioning of its epithelial face, combination with tarsorrhaphy, duration of postoperative follow-up, probable cause of failure, uncorrected visual acuity before and after surgery, persistent epithelial defect or con-
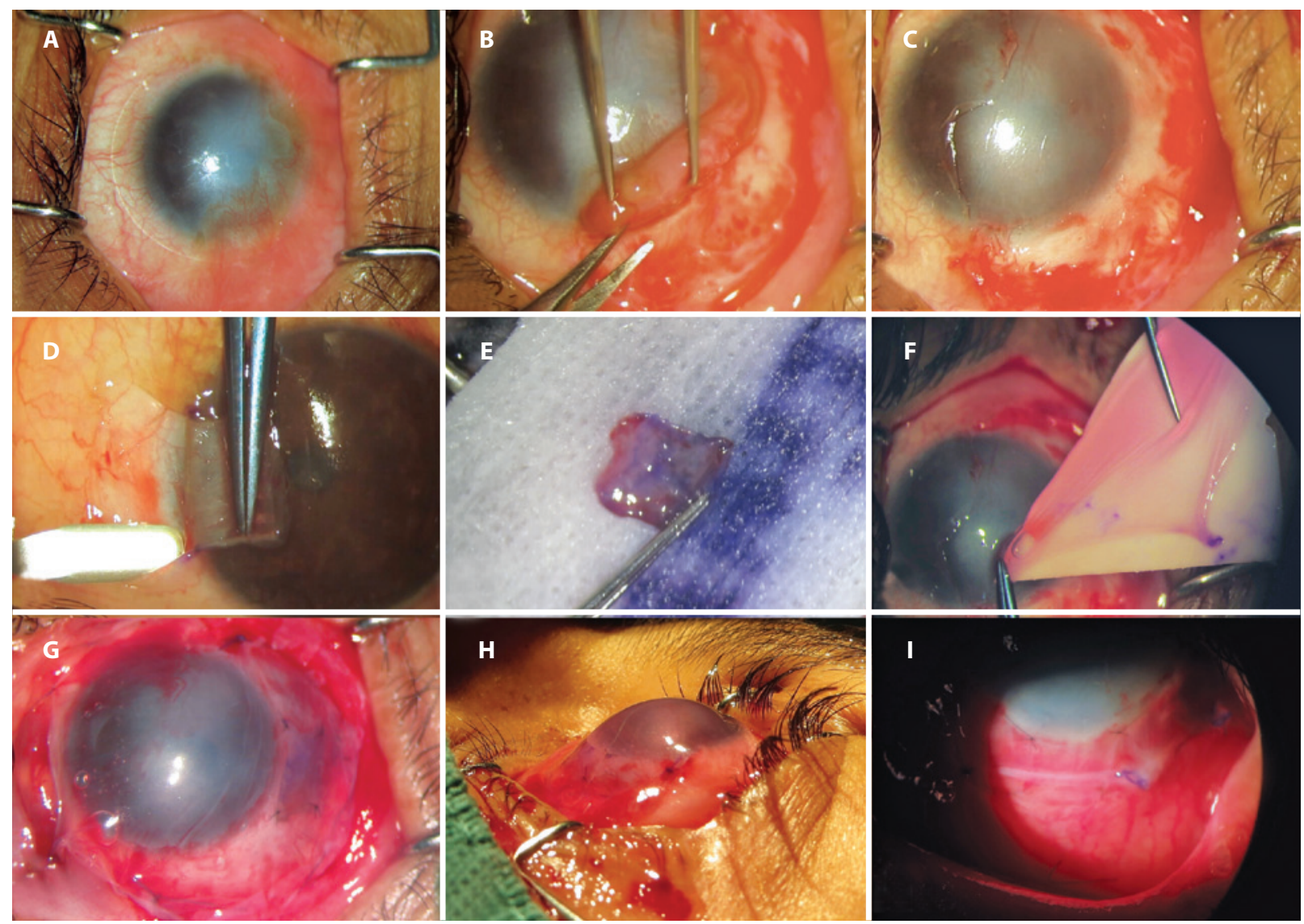

Figure 1. Surgical steps in a case of homologous limbal stem cell transplantation. A) preoperative photograph of a case of unilateral limbal stem cell deficiency; B) removal of fibrovascular tissue from corneal and scleral surfaces; C) underlying corneal and scleral bed preparation; D) autologous limbal tissue dissected from contralateral healthy eye at 6 o'clock position; E) autologous limbal tissue ready for transplantation; F) amniotic membrane transplantation; G) autologous limbal tissue sutured in place at 6 o'clock position under amniotic membrane transplantation (epithelial face down); $\mathrm{H}$ ) immediate postoperative photograph; I) postoperative photograph on the seventh day. 
junctivalization of the cornea after surgery, improvement of corneal transparency, and postoperative complications.

In cases where persistent epithelial defect or conjunctivalization was not detected during the postoperative follow-up, the intervention was defined as a surgical success. All biomicroscopic findings reported that suggested failure, such as ischemia, melting, presumed rejection, necrosis, epithelial defect, or conjunctivalization were defined as failures.

Kaplan-Meier survival analysis was performed to evaluate conjunctival limbal graft survival.

\section{RESULTS}

The preoperative evaluation was performed for all 28 patients, from groups I and II, included in the study (Table 1).

Of the total sample of 28 patients, $53.6 \%(n=15)$ underwent a CLAU and constituted group I, whereas $46.4 \%(n=13)$ underwent a CLAL and constituted group II.

Males were predominant in both groups (Table 1), and consequently, constituted the majority of the overall population studied: $67.9 \%(n=19)$. Right eyes were the most prevalent in the overal sample, at 67.9\% $(n=19)$, with $73.3 \%(n=11)$ in group I and $61.5 \%$ $(n=8)$ in group II.

In relation to patient age at the time of surgical intervention, the mean age was 40.33 years (5-82 years). A higher mean age was found in group I, as seen in Table 1.

The groups differed with respect to bilaterality. Unilateral cases predominated in group I and bilateral cases predominated in group || as shown in table 1. In the overall analysis, unilateral cases accounted for $60.7 \%(n=17)$ and bilateral for $39.2 \%(n=11)$.

The most frequent pathology causing limbal stem cell deficiency among the entire study population was chemical burns (53\%), followed by thermal burns $(20.0 \%, n=3)$ and failure secondary to multiple surgical procedures $(13.3 \%, \mathrm{n}=2)$ in group I, and by Stevens-Johnson syndrome $(23.0 \%, \mathrm{n}=3)$, and atrophy, aniridia, and brachytherapy (each corresponding to $7.6 \%, \mathrm{n}=1$ ) in group II.

The duration of time of disease progression from diagnosis until surgery ranged from 1 month to 52 years, with an average of 11.18 years (Table 1).

The extension of donor limbal tissue transplanted was evaluated and the results are shown in table 1. The limbal tissue extension most used in the study was $120^{\circ}$, at $31.2 \%(n=5)$.

The groups were evaluated regarding the use of AM during surgery, as well as the positioning of its epithelial face. AM was used in the majority of the patients in the study: $75.0 \%(n=21)$; with $80.0 \%$ $(n=12)$ in group I and $69.2 \%(n=9)$ in group II. In group I, the medical records of four cases did not contain information about the positioning of the membrane. For the rest of the cases, the membrane was positioned with the epithelial face downward (functioning as a con-

Table 1. Epidemiological characteristics of the study population

\begin{tabular}{lcc}
\hline Epidemiological characteristics & $\begin{array}{c}\text { Group I (n=15) } \\
\text { autologous } \\
\text { transplantation } \\
\text { (CLAU) }\end{array}$ & $\begin{array}{c}\text { Group II (n=13) } \\
\text { allogenic } \\
\text { transplantation } \\
\text { (CLAL) }\end{array}$ \\
\hline Age (years) & $48.83(29-82)$ & $31.83(5-63)$ \\
Sex (male/female) & $11 / 4$ & $8 / 5$ \\
Bilaterality & $2(13.3 \%)$ & $9(69.2 \%)$ \\
Mean time until surgery (years) & 9.61 & 12.62 \\
Limbal extension used & $\leq 120^{\circ}(100 \%)$ & $\geq 120^{\circ}(87.5 \%)$ \\
Use of amniotic membrane & $12(80.0 \%)$ & $9(69.2 \%)$ \\
Tarsorrhaphy & $6(40.0 \%)$ & $10(76.9 \%)$ \\
Mean postoperative follow-up (months) & 18.36 & 35.04 \\
\hline
\end{tabular}

tact lens) in four cases and upward (functioning as a basement membrane to stimulate epithelialization) in three cases. The "sandwich" technique (membrane facing both upward and downward) was used in only one patient in group I. In group II, there was no information about the positioning of the membrane in five cases; upward-facing positioning was used in three cases and downward in only one case.

Tarsorrhaphy and LSCT were common in group II (Table 1); this procedure was performed in $57.1 \%(n=16)$ of all cases.

With respect to the limbus donated for allogenic transplants, most came from a family member (Ir-CLAL, 66.6\%, $n=8)$, and in all cases, the relative was a sibling. The $c-C L A L$ accounted for $33.3 \%(n=4)$ of surgeries in group II. HLA compatibility analysis was performed in all patients in group II, but data was not available in the medical records. As a standard procedure, a minimum $75 \%$ match is required for an Ir-CLAL.

Follow-up time ranged from 1 to 60 months, with an average of 24.84 months. Only one patient (group I) had a follow-up of 1 month due to early failure of the graft and did not return to continue treatment. This patient was included as a failure in the statistical analysis, and the complication was reported. All other patients in the study had a minimum follow-up of 6 months. The mean follow-up time for each group is found in table 1 .

There was improvement in the uncorrected visual acuity in 38\% of all cases $(n=8)$, no change in $28.5 \%(n=6)$, and deterioration in $33.3 \%(n=7)$.

The postoperative results were obtained from the medical records, with a focus on persistent epithelial defect, conjunctivalization, and improved transparency. No persistent epithelial defect was found in the majority $(75.0 \%$ of the total study population; $n=21)$ of the patients in both groups as depicted in table 2 . The conjunctivalization rate was similar between the two groups, at $53.3 \%(n=8)$ in group I and $58.3 \%(n=7)$ in group II. Improved transparency occurred in only $38.4 \%(n=10)$ of the cases, corresponding to $46.6 \%(n=7)$ of the cases in group I and $23.07 \%(n=3)$ of the cases in group II.

Surgery was considered successful when there were no reports of persistent epithelial defect or conjunctivalization during the postoperative follow-up. Any biomicroscopic signs suggesting failure of the graft, such as ischemia, melting, presumed rejection, necrosis, epithelial defect, or conjunctivalization, were considered as surgical failures. Using these criteria, the success rate was eight out of $28 \mathrm{pa}-$ tients, which constitutes $28.5 \%$ of all surgeries performed. The LSCT success rates in groups I and II can be seen in table 2 .

Among those cases considered to be failures, the average time between surgery and diagnosis of failure was approximately 2 months, and was similar between the two groups (Table 2).

Kaplan-Meier survival analysis was applied to evaluate conjunctival limbal graft survival. In group I, graft survival was seen in six eyes $(43 \%)$ at 1 year and in three eyes $(21 \%)$ at 3 years, with a cumulative survival of $21 \%$ after a mean follow-up time of 18.36 months. In group II, survival was seen in three eyes (38\%) at 1 year and in two eyes (15\%) at 3 years, with a cumulative survival of 15\% after a mean follow-up time of 35.04 months (Figure 2).

The most prevalent complication was persistent epithelial defect, which occurred in $25.0 \%$ of the cases $(n=7)$, followed by melting in $14.2 \%(n=4)$. The other complications observed include infectious ulcers, limbal graft necrosis or ischemia, perforation, and descemetocele; their prevalence in each group is shown in table 2.

\section{DISCUSSION}

Many studies have already reported that limbal stem cells are the source of epithelial renewal and regeneration under normal or injury conditions ${ }^{(3)}$.

The replacement of limbal stem cells through LSCT, is one of the most effective methods for treating limbal stem cell deficiency ${ }^{(6,7)}$. The technique is chosen depending on the extent and severity of 
Table 2. Postoperative results: complications and success rates

\begin{tabular}{lccc}
\hline Results & $\begin{array}{c}\text { Group I } \\
(\mathbf{n = 1 5 )}\end{array}$ & $\begin{array}{c}\text { Group II } \\
(\mathbf{n = 1 3 )}\end{array}$ & $\begin{array}{c}\text { Total } \\
(\mathbf{n = 2 8})\end{array}$ \\
\hline Persistent epithelial defect & $2(13.30 \%)$ & $5(38.4 \%)$ & $7(25.0 \%)$ \\
Melting & $1(6.60 \%)$ & $3(23.0 \%)$ & $4(14.2 \%)$ \\
Graft necrosis or ischemia & 0 & $2(15.3 \%)$ & $2(7.1 \%)$ \\
Descemetocele & 0 & $2(15.3 \%)$ & $2(7.1 \%)$ \\
Infectious ulcer & 0 & $1(7.6 \%)$ & $1(3.5 \%)$ \\
Perforation & 0 & $1(7.6 \%)$ & $1(3.5 \%)$ \\
Surgical success & $5(33.00 \%)$ & $3(23.0 \%)$ & $8(28.5 \%)$ \\
Time to surgical failure (months) & 2.16 & 2.25 & 2.21 \\
\hline
\end{tabular}

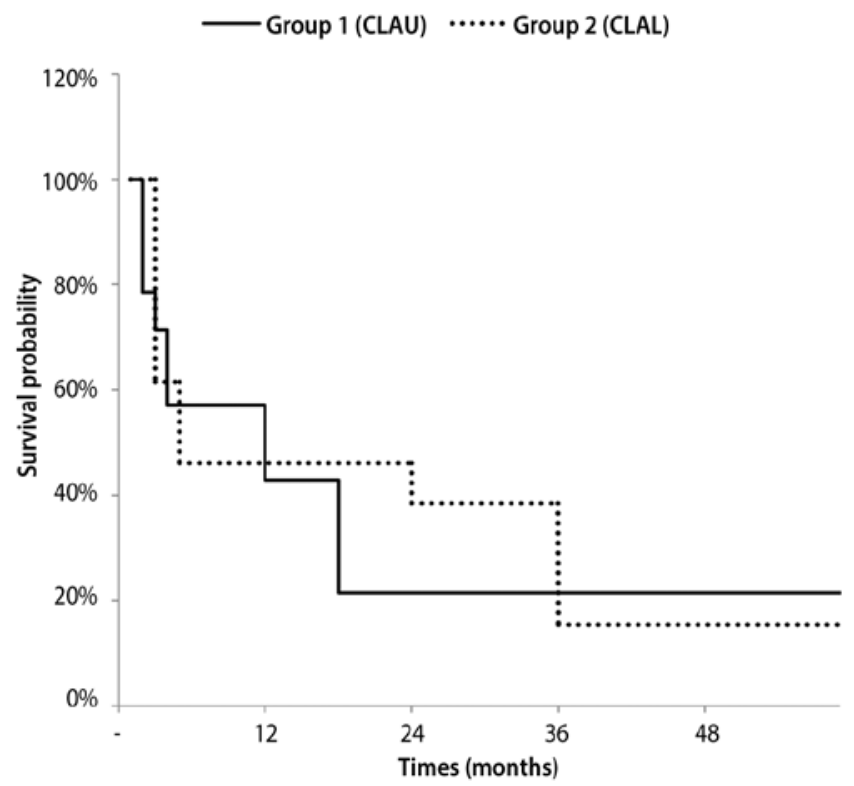

Figure 2. Kaplan-Meier survival curve of autologous grafts (group I) and allogenic grafts (group II).

damage to the limbal function and the clinical conditions of the contralateral eye. Therefore, in situations where it is unilateral and unifocal, an ipsilateral CLAU can be performed. When the unilateral damage is more extensive, the contralateral limbus can be used (contralateral CLAU). On the other hand, for bilateral situations, the limbus of close relatives or a cadaver is used ${ }^{(6)}$. For CLAL, HLA typing analysis is necessary and the use of systemic immunosuppression is considered $^{(6,7)}$.

In this study, the male sex (67.9\%) and right eye were more commonly affected. A previous small series has also reported a higher prevalence among males ${ }^{(8)}$. Since the main cause of limbal stem cell deficiency in this study was chemical injury, we believe that the higher incidence in males may be related to greater occupational exposure in males.

The distribution of patients in groups I and II took into account the severity and unilaterality or bilaterality. This fact limits comparisons between the two groups insofar as the success and failure rates of the treatments applied, since it involved patients with different clinical profiles who also underwent distinct surgical procedures. Success rate analysis should also take into consideration the technical inexperience of surgeons who were still learning.
Only $13.3 \%(n=2)$ of the 15 patients in group I had bilateral disease, whereas $69.2 \%$ of the cases in group II had bilateral involvement $(n=9)$. In the two cases where there was bilateral disease and CLAU was performed, the patients had partial and localized limbal failure in the least affected eye caused by chemical burns. In group II, four patients had unilateral disease (30.8\%), and despite this, underwent $\mathrm{CLAL}$. Three of them had previously undergone unsuccessful CLAU and one had a contralateral eye in phthisis bulbi.

The literature on the subject indicates that chemical injury is largely responsible for most cases of limbal failure ${ }^{(7)}$, which we also found to be the case in our study $(n=15 ; 53.5 \%)$. Other causes included thermal burns $(n=3 ; 10.7 \%)$ and Stevens-Johnson syndrome $(n=3 ; 10.7 \%)$. Santos et al. evaluated 33 eyes with limbal stem cell deficiency, and of these, $67 \%$ were secondary to chemical trauma and $33 \%$ due to Stevens-Johnson syndrome ${ }^{(9)}$. In an extensive literature review, Cauchi et al. reported that $50 \%$ of the cases of bilateral limbal stem cell deficiency were caused by chemical burns, whereas this same etiology was responsible for $100 \%$ of the cases of unilateral limbal stem cell deficiency ${ }^{(10)}$.

The use of AM has already been well documented in the treatment of cutaneous ulcers ${ }^{(11-14)}$. It was first used in ophthalmology in 1940 to treat conjunctival defects(15-17). AM works in a therapeutic manner, with specific properties that promote ocular surface repair, such as anti-adhesive and antibacterial effects, wound protection, pain reduction, and especially, in promoting reepithelialization ${ }^{(11-14,18,19)}$. It can also serve as a barrier against fibroblast proliferation and exhibits low immunogenicity due to not exhibiting higher histocompatibility antigens (HLA-A, B, or DR), which prevents rejection in the host ${ }^{(20)}$.

Some encouraging results have been published in terms of ocular surface reconstruction using $\mathrm{AM}^{(7)}$. Its use may provide a more suitable environment for cell proliferation than the previously inflamed perilimbal environment, thus increasing the chances of successful ocular surface reconstruction ${ }^{(7)}$. In this study, AM was used in $75 \%$ of the cases.

Another important contributing factor in corneal epithelialization in ocular surface reconstruction surgeries is tarsorrhaphy ${ }^{(21)}$. Besides reducing tear film evaporation, it also reduces the traumatic effect caused by blinking ${ }^{(21)}$. Tarsorrhaphy was used in conjunction with LSCT in 57\% of the overall population in the study and was performed in group II in $77 \%$ of the procedures. Since group II was comprised of patients with greater clinical severity, and for the most part, with bilateral conditions, this explains the higher use of tarsorrhaphy as an adjunct in this group of patients.

The definition of surgical success in studies on limbal stem cell deficiency varies in the literature, but it mostly includes reepithelialization and visual results, which respectively indicate anatomical and functional recovery of the ocular surface ${ }^{(22-24)}$.

Shimazaki et al. used the detection of donor tissue-derived epithelial cells in patients who underwent heterologous LSCT combined with penetrating keratoplasty, comparing with isolated cases of penetrating keratoplasty as controls. This study suggested the long-term effectiveness of CLAL in providing epithelial cells from tissue transplanted to the ocular surface ${ }^{(24)}$.

Ilari et al. studied 23 eyes with severe ocular surface disorders that underwent CLAL, and evaluated the reepithelialization and stabilization of the whole epithelium over a mean follow-up period of 60 months. They detected primary failure (eyes that never reepithelized) in $24.2 \%$ of the cases. Only $21.2 \%$ of the cases retained an intact epithelium throughout the follow-up ${ }^{(25)}$.

In another study that evaluated the results of LSCT combined with penetrating keratoplasty, Reinhard et al. detected central transparency in 30\% of the grafts after 5 years of postoperative follow-up. Additionally, there was an improvement in visual acuity from 0.02 to 0.24 in patients with a clear graft and from 0.02 to 0.03 in cases of failure. The best visual acuity observed after long-term follow-up was 0.45 in patients with a clear graft and 0.26 in cases of failure(23). 
Solomon et al. evaluated 39 eyes that underwent CLAL with AM, with or without penetrating keratoplasty, and found that the overall survival of ambulatory vision (deemed as visual acuity greater than 0.1 ) was $53.6 \%$ at 3 years and $44.6 \%$ at 5 years ${ }^{(26)}$

A retrospective study such as the present study tends to obtain visual acuity as measured using a Snellen chart by different examiners and/or environments with non-standardized lighting. For this reason, visual acuity was not included as a criterion for evaluating surgical success. In this study, the absence of epithelial defects and conjunctivalization during postoperative follow-up were considered as variables indicating surgical success and totaled $28.5 \%(n=8)$ of the sample population. The success rate in groups I and II were $33.0 \%$ $(n=5)$ and $23.0 \%(n=3)$, respectively. Again, it is worth noting the inclusion of patients with more severe and mostly bilateral clinical profiles in group II, requiring allogenic transplantation, which prevents the comparison of the success rates between the two groups.

The length of follow-up time may be directly related to the survival rate of limbal grafts. Santos et al. found a cumulative survival rate of $80 \%$ for CLAU and $13 \%$ for CLAL after 33 months of follow-up ${ }^{(9)}$. Solomon et al. noted a progressive decrease in the survival rates of keratolimbal allogenic grafts over 5 years of follow-up, with $76.9 \%$ at 1 year, $47.4 \%$ at 3 years, and $23.7 \%$ at 5 years ${ }^{(26)}$. This study also found a better survival rate when LSCT was performed as an isolated procedure, as opposed to the procedure being combined with penetrating keratoplasty, with rates of $81.2 \%$ for the former and $58.9 \%$ for the latter at 2 years. Furthermore, when necessary, a limbal retransplantation had a higher survival rate at 2 years than the first procedure, with rates of $68.2 \%$ and $27.3 \%$, respectively $(p=0.041)$. In a study of 23 eyes with severe ocular surface disorders that underwent CLAL, Ilari et al. found survival rates of $54.4 \%$ at 1 year, 33.3\% at 2 years, and $27.3 \%$ at 3 years ${ }^{(25)}$.

The mean follow-up time of patients in this study was 24.84 months; a longer follow-up period would be required to estimate the long-term success rate of these patients.

The survival rate can also be influenced by HLA compatibility in cases of CLAL. Reinhard et al. found a variable survival rate at 5 years that was dependent on HLA compatibility, at $65 \%$ for incompatibility of 0-1 alleles, $41 \%$ for incompatibility of 2-6 alleles, and 14\% for total incompatibility of alleles $(p=0.03)^{(23)}$. In this study, the donor tissue was from a family member $(66.6 \%, n=8)$ for the majority of the allogenic transplants, and the limbus taken from cadavers accounted for $33.3 \%(n=4)$. HLA compatibility analysis was performed for all patients in group II, but the data was not available in the medical records. As a standard procedure, a minimum of $75 \%$ class I and II HLA match is required for an $\mathrm{Ir}-\mathrm{CLAL}$.

Despite the variety of surgical procedures for ocular surface restoration, the success rate of current techniques decreases over time, ranging from $40-80 \%$ during the first year to $33-50 \%$ over 2 years ${ }^{(8,9,27)}$. Taking into account the relatively low medium-term success rates, it is worth considering alternative therapies, such as keratoprosthesis implantation. The anatomic and functional results reported in the literature support the use of Boston type 1 keratoprosthesis for managing bilateral limbal stem cell dysfunction secondary to chemical burn ${ }^{(28,29)}$. Another interesting option is the combination of regenerative medicine based on regenerative cell therapy (isolation and transfer of undifferentiated cells) ${ }^{(30)}$. Cell therapy, consisting of undifferentiated stem cells, can be genetically modified before they are transplanted to the recipient, which would not only offer a regenerative therapeutic alternative, but at the same time, provide a lasting and stable genic presence of therapeutic genes in the progenesis of these cells.

Despite this unfavorable long-term prognosis, LSCT still provides acceptable results in developing countries through a relatively simple, low-cost procedure, and continues to be a therapeutic alternative for cases of unilateral or bilateral limbal stem cell deficiency.

\section{REFERENCES}

1. Tsai RJF, Tseng SCG. Human allograft transplantation for corneal surface reconstruction. Cornea. 1994;13(5):389-400.

2. Vogt A. The limbus. In: Textbook and Atlas of Slit Lamp Microscopy of the Living Eye. 3 ed. Wayenborgh: Bonn-Bad Godsberg, 1921; p.52-3.

3. Davenger M, Evensen A. Role of the pericorneal papillary structure in renewal of corneal epithelium. Nature. 1971;229(5286):560-1.

4. Thoft RA, Friend J. The X, Y, Z hypothesis of corneal epithelial maintenance. Invest Ophthalmol Vis Sci. 1983;24(10):1442-3.

5. Pellegrini G, Traveso CE, Franzi AT, Zingirian M, Cancedda R, De Luca M. Long term restoration of damaged corneal surfaces with autologous cultivated corneal epithelium. Lancet. 1997;349(9057):990-3. Comment in: Lancet. 1997 24;349(9064):1556.

6. Tseng SCG, Chen JJY, Huang AJW, Kruse FE, Maskin SL, Tsai RJF. Classification of conjunctival surgeries for corneal diseases based on stem cell concept. Ophthalmol Clin North Am. 1990;3:595-610.

7. Shimazaki J, Yang HY, Tsubota K. Amniotic membrane transplantation for ocular surface reconstruction in patients with chemical and thermal burns. Ophthalmology. 1997;104(12):2068-76.

8. Gomes JAP, Santos MS, Cunha MC, Mascaro VLD, Barros JN, Sousa LB. Amniotic membrane transplantation for partial and total limbal stem cell deficiency secondary to chemical burn. Ophthalmology, 2003:110(3):466-73.

9. Santos MS, Gomes JA, Hofling-Lima AL, Rizzo LV, Romano AC, Belfort R. Survival analysis of conjunctival limbal grafts and amniotic membrane transplantation in eyes with total limbal stem cell deficiency. Am J Ophthalmol. 2005;140(2):223-30.

10. Cauchi PA, Ang GS, Azuara-Blanco A, Burr JM. A systematic literature review of surgical interventions for limbal stem cell deficiency in humans. Am J Ophthalmol. 2008; 146(2):251-9.

11. Trelford JD, Trelford-Sauder M. The amnion in surgery, past and present. Am J Obstet Gynecol. 1979;134(7):833-45.

12. Colocho G, Graham WP, Greene AE, Matheson DW, Lynch D. Human amniotic membrane as a physiologic wound dressing. Arch Surg. 1974;109(3):370-3.

13. Prasad JK, Feller I, Thompson PD. Use of amnion for the treatment of Stevens-Johnsons syndrome. J Trauma. 1986;26(10):945-6.

14. Van der Linden PJ, de Goeij AF, Dunselman GA, Erkens HW, Evers JL. Endometrial cell adhesion in an in vitro model using intact amniotic membranes. Fertil Steril. 1996;65(1):76-80.

15. de Rötth A. Plastic repair of conjunctival defects with fetal membranes. Arch Ophthalmol. 1940;23(3):522-5

16. Lavary W. Lime burns of conjunctiva and cornea treated with amnioplastin graft. Trans Ophthalmol Soc UK. 1946;66:668-71.

17. Sorsby A, Haythorne J, Reed H. Amniotic membrane grafts in caustic soda burns. $\mathrm{Br}$ J Ophthalmol. 1947;31(7):409-18.

18. Marinho D, Hofling-Lima A, Kwitko S, Tseng SC. Does amniotic membrane improve limbal alografts? Cornea. 2003;22(4):338-42

19. Tayyar M, Turan R, Ayata D. The use of amniotic membrane plus heparin to prevent postoperative adhesions in the rabbit. Tokai J Exp Clin Med. 1993;18(1-2):57-60.

20. Akle CA, Adinolfi M, Welsh KI, Leibowitz S, McColl I. Immunogenicity of human amniotic epithelial cells after transplantation into volunteers. Lancet. 1981;2(8254): 103-7

21. Tzelikis PFM, Diniz CM, Tanure MAG, Trindade FC. Tarsorrafia: aplicações em um Serviço de Córnea/ Tarsorrhaphy: applications in a Cornea Service. Arq Bras Oftalmol. 2005;68(1):103-7.

22. Samson CM, Nduaguba C, Baltatzis S, Foster CS. Limbal stem cell transplantation in chronic inflammatory eye disease. Ophthalmology. 2002;109(5):862-8.

23. Reinhard T, Spelsberg $H$, Henke L, Kontopoulos T, Enczmann J, Wernet $P$, et al. Long-term results of allogeneic penetrating limbo-keratoplasty in total limbal stem cell deficiency. Ophthalmology. 2004 Apr;111(4):775-82.

24. Shimazaki J, Kaido M, Shinozaki N, Shimmura S, Munkhbat B, Hagihara M, et al. Evidence of long-term survival of donor-derived cells after limbal allograft transplantation. Invest Ophthalmol Vis Sci. 1999 Jul;40(8):1664-8.

25. Ilari L, Daya SM. Long-term outcomes of keratolimbal allograft for the treatment of severe ocular surface disorders. Ophthalmology. 2002;109(7):1278-84.

26. Solomon A, Ellies $\mathrm{P}$, Anderson DF, et al. Long-term outcome of keratolimbal allograft with or without penetrating keratoplasty for total limbal stem cell deficiency. Ophthalmology. 2002;109(6):1159-66. Comment in: Ophthalmology. 2003;110(10): 2071; author reply 2071-2.

27. Tseng SC, Prabhasawat $\mathrm{P}$, Barton $\mathrm{K}$, et al. Amniotic membrane transplantation with or without limbal allografts for corneal surface reconstruction in patients with limbal stem cell deficiency. Arch Ophthalmol. 1998;116(4):431-41.

28. Harissi-Dagher M, Dohlman CH. The Boston Keratoprosthesis in severe ocular trauma. Can J Ophthalmol. 2008;43(2):165-9.

29. Sejpal K, Yu F, Aldave AJ. The Boston Keratoprosthesis in the management of corneal limbal stem cell deficiency. Cornea. 2011 Nov;30(11):1187-94.

30. Oliveira LA, Kim C, Sousa LB, Schwab IR, Rosenblatt MI. Gene transfer to primary corneal epithelial cells with an integrating lentiviral vector. Arq Bras Oftalmol. 2010; 73(5):447-53. 